\title{
Improving the Creative Thinking Ability of Junior High School Students Through GeoGebra Assisted Learning Community in Mathematics
}

\author{
https://doi.org/10.3991/ijim.v15i22.24797 \\ Asri Ode Samura ${ }^{1,2(凶)}$, Darhim ${ }^{1,2}$, Dadang Juandi ${ }^{1,2}$, Arwan M. Said ${ }^{2}$, Muhlis Malaka ${ }^{2}$ \\ ${ }^{1}$ Universitas Pendidikan Indonesia, Bandung, Indonesia \\ ${ }^{2}$ Institut Agama Islam Negeri Ternate, Kota Ternate, Indonesia \\ asri22samura@upi.edu
}

\begin{abstract}
Learning Community is closely related to learning through community services, ICT, and other learning communities. GeoGebra is an interactive mathematics software for learning and teaching science, technology, engineering, and mathematics from elementary school to university. GeoGebra-assisted learning communities are beneficial if used, it can combine the learning process in the classroom when students talk to each other, share experiences, collaborate, and create more meaningful learning. The analysis and study results found differences between GeoGebra-assisted learning community learning and conventional learning towards increasing students' creative thinking skills in junior high schools. The learning community is learning that can improve students' creative thinking skills. Following the characteristics and development of the student learning environment, the implementation of the GeoGebra-assisted learning community is essential in mathematics. The method used in this study is a quantitative method, designed with an experimental pattern of nonequivalent control groups. The sample amounted to 79 people, which were taken from two classes that were not randomly assigned. The two classes, each class was given different treatment. One class was given with learning community assisted by GeoGebra, and the other class was given with conventional learning. Both classes were given a test to obtain data. The test was given twice, namely pretest and posttest. They measured the increase in creative thinking skills using Normalized N-Gain. Data were analyzed using an independent sample T-Test.
\end{abstract}

Keywords - creative thinking ability, GeoGebra-assisted learning community

\section{Introduction}

A severe problem that mathematics teachers face today is that students say mathematics is the most challenging subject. Because learning mathematics is always related to ideas and concepts that are abstract, hierarchically arranged, and the reasoning is deductive [1]. In learning mathematics, there should be no steps/concept stages that are skipped [2]. Mathematical concepts are arranged hierarchically, so learning Mathematics should be studied systematically and regularly and presented with a clear structure [3], [4]. Thus, learning mathematics will be carried out effectively and efficiently. 
Mathematics learning can be effective if the implementation allows students to learn efficiently, have fun, and achieve the expected goals [5]. Teachers can increase learning effectiveness to create brilliant ideas [6], [7]. Realizing the implementation of learning, teachers can design learning well to achieve their learning goals [8]. Developing a mathematics learning system requires an appropriate learning model [9].

Improving creative thinking skills in students is not an easy thing. Tricks and learning models are needed [10]. Teachers must innovate to apply creative thinking tricks and use learning models to improve creative thinking skills. Creative thinking can be said as a higher-order thinking ability. However, students' creative thinking skills are still far from expected [11], [12]. The suitable learning model to be used in improving creative thinking skills is the GeoGebra-assisted learning community model. The learning community model assisted by GeoGebra is an effective learning model to improve creative thinking skills. Using the GeoGebra learning community model [13], the teacher easily invites students to think positively, forcing students not to be affected by negative thoughts. Teachers can always motivate students to think positively. Using a learning community model assisted by GeoGebra, students are more active, creative, and innovative in speaking, sharing experiences, and collaborating with classmates to improve creative thinking skills [14].

Creativity in mathematics is generally emphasized on the ability to think creatively [15]. Most people who study mathematics do thinking activities. Creative thinking in mathematics combines logical thinking and divergent thinking based on intuition and mindful attention to flexibility, fluency, and novelty [16]. Creative thinking skills are classified as high-order competencies and can be seen as a continuation of essential competencies. Creative thinking can be referred to as basic skills in learning mathematics [17], [18]. Creative thinking is critical because this kind of ability is needed in solving problems in learning mathematics. Convergent mathematics learning activities can form basic skills [19]. These activities generally tend to be algorithmic, mechanistic, and routine math exercises [20]. The ability to think creatively is divergent and requires the activity of investigating mathematical problems from various perspectives. Through investigation, students can optimize their knowledge to solve various problems [21], [22].

Learning mathematics using computer-aided teaching materials will increase students' knowledge in exploring subject matter [23]. Students can present learning outcomes in an attractive form [24]. Learning to use computer-aided teaching materials is characterized by hardware in the learning process [25]. The software or hardware used in this study is GeoGebra. The subject matter is arranged in teaching materials delivered before the class; using GeoGebra software can make teaching easier for teachers [26]. Learning with the help of GeoGebra, the teacher's role is only as a facilitator [27]. Learning by utilizing computer media requires guidance from the teacher to facilitate student learning effectively [28]. The teacher gives full to students to develop a way of learning according to the characteristics or needs. The teacher acts as a programmer, always creative and innovative in using GeoGebra in the learning process.

As Dingyloudi et al. (2020) [29] stated, the Learning Community can positively impact improving learning outcomes. Learning Community is a learning model centered on Student-Centered Learning, centered on the concept of learning in groups, working together, sharing information, and can create an atmosphere of learning in a community 
forum. Learning with the community effectively forms creative thinking skills, including five aspects: thinking fluently, flexible, original, elaborative, and evaluative.

Many researchers have researched improving critical thinking and creative thinking skills using various models or learning methods. Improving the ability to think critically or creatively using the learning community model has been widely practiced in the humanities, social sciences, and natural sciences. There has never been another research using the learning community in mathematics. Researchers conducted research using a learning community assisted by GeoGebra in junior high school mathematics subjects this time.

Referring to the description above, the researcher at this moment conducts an in-depth, comprehensive study of student's creative thinking skills using GeoGebra Assisted Learning Community. The researcher raised the research with "Improving the Creative Thinking Ability of Middle School Students Using GeoGebra Assisted Learning Community" to obtain a comprehensive study.

\section{Learning community}

Learning community is a learning model using a study group work system, which has been determined to achieve the objectives [30]. A learning community can also be said as a group of people who exchange common values or beliefs and actively agree to learn together with one another [31]. Even though learning a working group is held, the principle of independence should not be forgotten not to harm each other [32]. The group work in question is responsible. Wheeler (2020) [33] says that when viewed from an educational point of view, the learning community is that teaching and learning activities are always carried out by teachers or students in the school environment.

Gibson et al. (2020) [34] say that the learning community is closely related to community services, ICT, and other learning communities. Learning community is used to describe a combination that one can think of to be interested in education. Sætra (2021) [35] describes three essential elements for a learning community: focus on learning (ensure that students learn), collaboration, and a results-oriented culture. What is meant by centralizing learning is to ensure whether students absorb the learning provided or not. Cooperation culture is defined as a superior cooperation culture that can create maximum cooperation results in a conducive, pleasant, mutual respect and open atmosphere. It results from orientation, namely the ability to maintain a high personal commitment to completing tasks, be reliable, responsible, and systematically identify risks and opportunities by paying attention to the relationship between planning and results for organizational success [36].

The keywords of the learning community are talking and sharing experiences with others, collaborating with others to create better learning compared to learning alone [37]. The purpose of the statement above is that learning outcomes should be obtained from collaborating with other people. Learning outcomes can be obtained in various ways, such as discussions between those who understand or do not, both inside and outside the classroom [38]. Therefore, learning packaged in group discussions with heterogeneous members and varying numbers strongly supports the learning community learning model [39]. 


\section{$3 \quad$ Research methods}

\subsection{Research design}

The research was designed using quantitative methods using nonequivalent control-group design experiments by applying GoeGebra Assisted Learning Community learning in mathematics learning [40]. As Ary et al. (2010) demonstrated, experimental research involves independent variables applied to a group to see the impact of the dependent variable. In this case, the independent variable is the learning applied to the experimental group. In contrast, the dependent variable is the creative thinking ability under study [42].

Before the treatment of learning implementation, each class was given a test in the form of a pretest to test students' creative thinking skills $(\mathrm{O})$. For each class, the implementation of learning was given a backtest in the form of a posttest equal to the pretest. The purpose of giving a pretest and posttest is to determine the increase in creative thinking ability to be measured. The class that implements learning with GeoGebra Assisted Learning Community is the experimental group (X). In contrast, the class that applies conventional learning without the assistance of GeoGebra is referred to as the control group (Figure 1).

Nonequivalent control-group study design.

\begin{tabular}{ccc}
\hline 0 & $X$ & 0 \\
\hline 0 & & 0 \\
\hline
\end{tabular}

Fig. 1. Nonequivalent control-group design

Comprehensively, this study examines and analyzes the influence of learning factors on increasing students' creative thinking skills.

\subsection{Sample}

The research sample was taken at one of the junior high schools in Ternate in the 2020/2021 academic year. The schools used as research samples have implemented the 2013 National Curriculum (K-13). Class VIII was used as the research sample, and two classes were selected as the research sample, one class as the experimental class, and one class as the control class. The experimental class was applied to a learning community assisted by GeoGebra, and the control class was given conventional learning. The accumulated number of students from both classes was 79 people.

\subsection{Research instruments}

Canals (2017) [41] stated that research instruments are tools used to obtain or collect data. The instrument used in the study was in the form of an essay test. The 
questions were set in the form of creative thinking skills. The purpose of preparing the test questions is to measure students' creative thinking skills. Several aspects must be considered in measuring students' creative thinking skills, including fluency, flexibility, novelty, and detail [43], [44].

a. Aspects of fluency include the ability to: (1) solve the problem and provide many answers to the problem; (2) provide many examples or statements related to certain mathematical concepts or situations.

b. Aspects of flexibility include the ability to: (1) use a variety of problem-solving strategies; (2) provide various examples or statements related to certain mathematical concepts or situations.

c. Novelty aspects include the ability to: (1) use strategies that are new, unique, or unusual to solve problems; (2) provide examples or statements that are new, unique, or unusual.

d. Aspects of detail include the ability to explain in detail, orderly, and coherently to specific mathematical procedures, answers, or mathematical situations.

The test of creative thinking skills in the research includes the material of straightline equations. There are eight questions in the form of a description with a processing time of $2 \times 40$ minutes. Implementation of the test after the entire learning process ends.

\subsection{Research procedure}

This research has two stages, namely the preparation stage (introduction) and implementation.

\section{a. Preparation Stage}

After the problem is formulated, the next step is to create learning instruments and devices. They validate research tools and instruments. Two teachers who have teaching experience in the field of mathematics education were determined to validate the instrument. Some students were selected for a limited trial. The aim was to determine the language readability level and get an idea of whether the instrument can be used in data collection. After validation and limited trials, further improvements and analysis were carried out to obtain a valid instrument.

b. Implementation Stage

Chose a school as a research location and managed research letters to related parties. Observed the research location and conduct discussions, questions, and answers between the research and mathematics subject teachers. Researchers and teachers determined the class/experimental group and control class as the research sample. The research flow can be described as follows (Figure 2). 


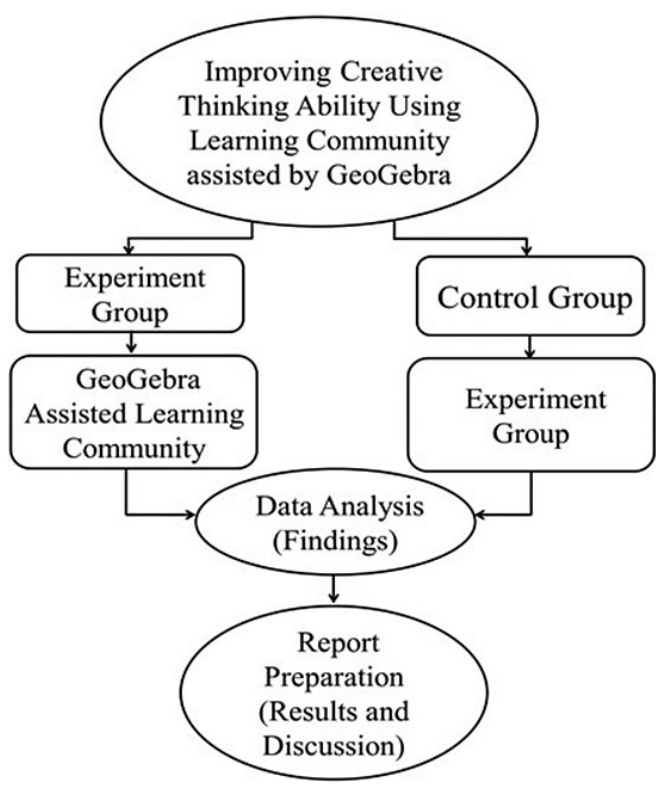

Fig. 2. Research flow

Before the beginning of the learning activities, the researcher gave a pretest of creative thinking skills. The next activity was implementing learning with the GeoGebra-assisted Learning Community carried out in the experimental group. Ordinary learning was applied to the control group. At the end of the meeting, both groups were given a posttest on creative thinking ability [45].

\subsection{Data analysis}

The students' creative thinking ability results were analyzed quantitatively by interpreting the results of statistical tests. Before carrying out statistical tests, tests for normality and homogeneity of variance were first performed. The steps of data processing in detail are described as follows.

a. Calculating the magnitude of the increase in students' creative thinking skills with the help of normalized gain. The normalized gain is seen from the comparison of the difference between the pretest score and the posttest score divided by the difference between the ideal maximum score and the pretest score [46], with the formula:

$$
\text { Gain Dernormalized }(g)=\frac{\text { Posttest score }- \text { Pretest score }}{\text { Ideal maximum score }- \text { Pretest score }}
$$

with gain index criteria in Table 1. 
Table 1. Criteria for normalized gain scores $(\mathrm{g})$

\begin{tabular}{|l|c|}
\hline \multicolumn{1}{|c|}{$(\mathrm{g})$} & Interpretation \\
\hline $\mathrm{g} \geq 0,70$ & High \\
\hline $0,30 \leq \mathrm{g}<0,70$ & Medium \\
\hline $\mathrm{g}<0,30$ & Low \\
\hline
\end{tabular}

b. Calculating descriptive statistics for pretest, posttest, and g scores.

Inferential statistical analysis with an independent sample t-test was used to evaluate data.

\section{$4 \quad$ Finding and discussion}

\section{1 $\quad$ Finding}

The results of the research and discussion are closely related to the research objectives. It showed on the results of the data analysis used to reveal and analyze the increase in students' creative thinking skills, where students who took part in learning with GeoGebra Assisted Learning Community and students who took part in direct learning.

The data collected in this study were quantitative data derived from the pretest and posttest results. Based on the analysis of research results in a comprehensive discussion, it is hoped that the research formulation described can be answered. The proposed hypothesis is proven so that the objectives of this study can be fulfilled.

Using the SPSS 21 software, the data were analyzed using descriptive and inferential statistics. Descriptive statistical analysis: To get an idea of ability before and after treatment in both groups of students. The inferential statistical analysis was carried out to conclude the improvement of students' creative thinking. In the following, data analysis and research results from testing the proposed hypothesis are presented, and a discussion of each related variable. First, the pretest-posttest and N-Gain data will be tested or analyzed to see the normality of the data, homogeneity, and comparison using the results of the t-test [47].

a. Data Normality Test

The normality test is intended to show whether the population sample is normally distributed or not [48]. The technique used in this test is the Kolmogorov-Smirnov test.

Table 2. Data normality test (Kolmogorov-Smirnov test)

\begin{tabular}{|l|c|c|c|c|c|c|}
\hline \multirow{3}{*}{ Name } & \multicolumn{3}{|c|}{$\begin{array}{c}\text { Learning Using GeoGebra Assisted } \\
\text { Learning Community }\end{array}$} & \multicolumn{3}{c|}{ Conventional Learning } \\
\cline { 2 - 7 } & Statistic & df & Sig. & Statistic & df & Sig. \\
\hline Pretest & .106 & 40 & .200 & .105 & 39 & .200 \\
\hline Posttest & .114 & 40 & .200 & .128 & 39 & .107 \\
\hline
\end{tabular}


Based on the results of the SPSS output above in Table 2, it is explained that the significance value of the two learnings, namely GeoGebr Assisted Learning Community and Conventional, on the pretest and posttest has a significance value more than $\alpha$, where $\alpha=0.05$. According to the decision-making rules in the normality test, it can be concluded that the data on GeoGebra and Conventional Assisted Learning Community learning is very normally distributed.

b. Homogeneity Test

The homogeneity test was carried out to show that the GeoGebra Assisted Learning Community learning data with conventional learning have the same variance or not. The decision-making technique for the homogeneity test refers to the significant results of the Test of Homogeneity of Variances [49].

Table 3. Test of homogeneity of learning outcomes with GeoGebra assisted learning community with conventional learning

\begin{tabular}{|c|c|c|c|}
\hline Levene Statistic & df1 & df2 & Sig. \\
\hline 1.530 & 3 & 154 & .209 \\
\hline
\end{tabular}

Based on Table 3 above, it is known that the significance value (sig.) of the learning outcomes variable for students who received GeoGebr Assisted Learning Community learning with conventional learning is 0.209 , and $=0.05$. Based on the homogeneity test decision making, it can be concluded that the variance of mathematics learning outcomes of students who received GeoGebr Assisted Learning Community learning with conventional learning is the same or homogeneous.

c. Independent Sample T-Test

The t-test was conducted to see the difference in creative thinking skills between students who received the GeoGebra Assisted Learning Community learning treatment and conventional learning. The table of differences in creative thinking abilities is as follows:

Table 4. Test of differences in creative thinking ability

\begin{tabular}{|l|l|c|c|c|c|c|}
\hline \multicolumn{2}{|c|}{ Name } & F & Sig. & T & df & $\begin{array}{c}\text { Sig. } \\
\text { (2-tailed) }\end{array}$ \\
\hline $\begin{array}{l}\text { N-Gain Class Learning } \\
\text { Community and } \\
\text { Conventional }\end{array}$ & Equal variances assumed & 1.691 & .197 & 12.770 & 77 & .000 \\
\cline { 2 - 7 } & Equal variances not assumed & & & 12.816 & 72.296 & .000 \\
\hline
\end{tabular}

Based on Table 4, it is known that the significance value (Sig. ( 2-tailed)) is 0.000 and $\alpha=0.05$. Based on the decision-making of the independent sample t-test, the conclusion is that there is a significant improvement between the learning outcomes of the GeoGebra Assisted Learning Community and conventional learning. 
d. Comparison of Learning Community with conventional learning

Table 5 shows a comparison of GeoGebra-assisted Learning Community with traditional learning.

Table 5. Comparison of the average value of $(\mathrm{g})$

\begin{tabular}{|l|l|c|c|c|}
\hline & \multicolumn{1}{|c|}{ Class } & N & Mean & Std. Deviation \\
\hline \multirow{2}{*}{ Learning outcomes } & Learning Community & 40 & .5890641 & .07922 \\
\cline { 2 - 5 } & Conventional & 39 & .3836 & .06046 \\
\hline
\end{tabular}

Comparison of the results between the two learning models can be seen in the average value $(\mathrm{g})$. Table 5 informs that the average value $(\mathrm{g})$ in classes with the application of Learning Community learning is 0.589. Learning in conventional classes has an average value of 0.3836 . Looking at the two average values between Learning Community and conventional learning, it can be said that the two learnings have very significant differences.

\subsection{Discussion}

Students ${ }^{\text {c }}$ creative thinking ability can be improved through communication with other people. The learning community concept suggests that thinking creatively is obtained through collaboration with other people [50]. Cooperation can take many forms, both informal study groups and in natural environments.

The learning community is carried out with a small study group system, different from conventional learning. Learning by using the Learning community is the same as learning with a peer tutor system. More capable students can teach the less capable ones, and those who understand teach those who do not. The ability to think creatively using the Learning community can be achieved because two-way learning communication is created [51].

The study results inform that the application of the learning community can run well because, at the time of application, there is communication between students and teachers. Students have an effective and communicative interaction. According to Piaget's theory, learning together or in groups can help improve students' abilities [52]. There was a significant learning process carried out in study groups, both homogeneously and heterogeneously. Geogebra-assisted Learning Community can create various problems (sharing problem), various information (sharing information), sharing experiences, and various problem solving (sharing problems), allowing the number of knowledge and skills obtained by students [53-54].

Referring to the research findings, the application of GeoGebra-assisted learning communities can significantly improve creative thinking skills compared to conventional learning. This comparison is seen from the average value of the normalized $\mathrm{N}$-Gain score in Table 5. The increase is based on the fact that the learning community starts from forming small study groups. More capable students can teach their friends, and students who understand can teach those who do not. Students are not asked to study on their own [3]. 
The problem-solving process was carried out in groups. The teacher gave students math problems, and students were asked to solve in groups, not individually. Each group leader plays a role in turning the group on in discussions to solve problems given by the teacher. Students who quickly understand the problem given by the teacher can explain to their group friends who do not. All group members have understood the problem. The group leader or secretary can record the discussion results to be presented in front of the class.

The group that has finished discussing appointed a group member to deliver the discussion results in front of the class so that other groups can listen. The group that conveyed the results of the discussion must pay attention and listen and ask questions. For questions asked from other groups, the group in charge of conveying the discussion results must answer them. The group member that answers the question does not have to be the group leader; the teammates may answer it. If the answers submitted are not appropriate or as expected, then the other groups may complete them. This kind of interaction can improve students' ${ }^{6}$ creative thinking skills.

The increase in creative thinking skills in applying the GeoGebra-assisted learning community reached a value of 0.75 or high criteria. However, even though implementing the gain test in the learning community class was quite good, there were several obstacles in implementing the learning. These obstacles occurred when conducting a learning community. At the beginning of learning using the learning community, students were very passive. In groups, some students were still busy working on their problems without collaborating with their friends. In addition, students were still shy to ask if they do not understand. These obstacles resulted in the implementation of the learning community is non-optimal. However, after the teacher provided motivation, guidance, and approach, the students confidently asked questions and discussed with their friends.

The application of the learning community with the help of GeoGebra in this lesson can improve creative thinking skills, which is shown in the normalized Gain test results. The results of the normalized gain test are depicted in Table 4, that the significance value is less than the value of the fundamental level $(\alpha)$. Based on the decision-making rules, it can be concluded that the application of the GeoGebra-assisted learning community further enhances creative thinking skills than conventional learning. The average value of the two learning models described in Table 5 is that students who study with the GeoGebra-assisted learning community model have a significant difference in the average value with ordinary or conventional learning.

The application of the GeoGebra-assisted learning community has several advantages in classroom learning. These advantages include: 1) Provide opportunities for students to continue to develop their abilities; 2) Students can improve their creative thinking or critical thinking skills; 3) Remind students of what they learned; 4) The selection of information is not determined by the teacher but based on the needs of students; 5) Fun in learning; 6) Students are more effective in solving problems in mathematics; and 7) The formation of good cooperation between individuals and groups. These advantages can encourage students to improve their creative thinking skills.

Referring to previous research conducted by Dingyloudi (2020) that Learning Community can positively impact learning outcomes, and associated with the findings in this study conducted on students in mathematics, it is evident that the learning 
community is a learning model that can improve thinking skills. Creative. The novelty of this research is that previous researchers in mathematics subjects have never studied it. The Learning community model, in its application, is focused on Student-Centered Learning. Students learn it centered on the concept of group learning, working together, sharing information, and building a learning atmosphere in a community forum.

\section{Conclusion}

The analysis results revealed that using the GeoGebra-assisted community learning model promotes the creative thinking skills of junior high school students. GeoGebra-assisted learning community learning model is appropriate for junior high school students because students can be quickly directed. The ability to think and reason can develop quickly for the better because creative problems always stimulate students.

\section{Acknowledgment}

The researchers would like to thank all those who contributed, from writing to data collection to compilation. The researchers also thanked the State Junior High School 3 Ternate Indonesia for allowing researchers to collect data for 12 days.

\section{$7 \quad$ References}

[1] Junarti, Sukestiyarno, Y. L., Mulyono, \& Dwidayati, N. K. (2019). The Profile of Structure Sense in Abstract Algebra Instruction in Indonesian Mathematics Education. European Journal of Educational Research, 8(4), 1081-1091.

[2] Alkhatib, A. S., \& Jaradat, S. A. (2021). The Impact of Blended Learning using the Ideas Box on the Motivation for Learning Among Non-formal Syrian Female Refugee Students in Jordan. International Journal of Interactive Mobile Technologies, 15(11), 81-95. https://doi. org/10.3991/ijim.v15i11.21961

[3] Askey, R. (2018). What Content Knowledge Should We Expect in Mathematics Education? 219-231. https://doi.org/10.1007/978-3-319-61434-2_11

[4] Widodo, S., \& Wahyudin. (2018). Selection of Learning Media Mathematics for Junior School Students. Turkish Online Journal of Educational Technology-TOJET, 17(1), 154-160. http://ezproxy.lib.uconn.edu/login?url=https://search.ebscohost.com/login.aspx?direct= true $\& \mathrm{db}=$ eric \&AN=EJ1165728\&site=ehost-live

[5] Hasan, R., Palaniappan, S., Mahmood, S., Sarker, K. U., Sattar, M. U., Abbas, A., Naidu, V. R., \& Rajegowda, P. M. (2021). eDify: Enhancing Teaching and Learning Process by Using Video Streaming Server. International Journal of Interactive Mobile Technologies, 15(11), 49-65. https://doi.org/10.3991/ijim.v15i11.20245

[6] Can, D., Özer, A., \& Durmaz, B. (2020). Views of Pre-service Primary School Teachers About the Integration of Children's Literature in Mathematics Teaching. International Journal of Progressive Education, 16(4), 99-114. https://doi.org/10.29329/ijpe.2020.268.7

[7] Harrison, T. R., \& Lee, H. S. (2018). Ipads in the Mathematics Classroom: Developing Criteria for Selecting Appropriate Learning Apps. International Journal of Education in Mathematics, Science and Technology, 6(2), 155-172. https://doi.org/10.18404/ijemst.408939 
[8] Vaiopoulou, J., Papadakis, S., Sifaki, E., Stamovlasis, D., \& Kalogiannakis, M. (2021). Parents' Perceptions of Educational Apps Use for Kindergarten Children: Development and Validation of a New Instrument (PEAU-p) and Exploration of Parents' Profiles. Behavioral Sciences, 11(6), 82. https://doi.org/10.3390/bs11060082

[9] Tanudjaya, C. P., \& Doorman, M. (2020). Examining Higher Order Thinking in Indonesian Lower. Journal on Mathematics Education, 11(2), 277-300. https://doi.org/10.22342/ ime.11.2.11000.277-300

[10] Papadakis, S. (2021). Advances in Mobile Learning Educational Research (AMLER): Mobile Learning as an Educational Reform. Advances in Mobile Learning Educational Research, 1(1), 1-4. https://doi.org/10.25082/AMLER.2021.01.001

[11] Papadakis, S., Kalogiannakis, M., \& Zaranis, N. (2021). Teaching Mathematics With Mobile Devices and the Realistic Mathematical Education (RME) Approach in Kindergarten. Advances in Mobile Learning Educational Research, 1(1), 5-18. https://doi.org/10.25082/ AMLER.2021.01.002

[12] Hidayah, I., Isnarto, Masrukan, Asikin, M., \& Margunani. (2020). Quality Management of Mathematics Manipulative Products to Support Students' Higher Order Thinking Skills. International Journal of Instruction, 14(1), 537-554. https://doi.org/10.29333/ iii.2021.14132a

[13] Tzagkaraki, E., Papadakis, S., \& Kalogiannakis, M. (2021). Exploring the Use of Educational Robotics in Primary School and Its Possible Place in the Curricula. In Educational Robotics International Conference (pp. 216-229). Springer, Cham. https://doi.org/10.1007/ 978-3-030-77022-8 19

[14] Barber, W. (2020). Building Creative, Critical Online Learning Communities Through Digital Moments. Electronic Journal of E-Learning, 18(5), 387-396. https://doi.org/10.34190/ JEL.18.5.002

[15] Schoevers, E. M., Kroesbergen, E. H., \& Kattou, M. (2020). Mathematical Creativity: A Combination of Domain-general Creative and Domain-specific Mathematical Skills. Journal of Creative Behavior, 54(2), 242-252. https://doi.org/10.1002/jocb.361

[16] BİNGÖLBALİ, E., \& BİNGÖLBALİ, F. (2020). Divergent Thinking and Convergent Thinking: Are They Promoted in Mathematics Textbooks? International Journal of Contemporary Educational Research, 7(1), 240-252. https://doi.org/10.33200/ijcer.689555

[17] Mainali, B. (2021). Representation in Teaching and Learning Mathematics. International Journal of Education in Mathematics, Science and Technology, 9(1), 1-21. https://doi.org/ 10.46328/ijemst. 1111

[18] Sheromova, T. S., Khuziakhmetov, A. N., Kazinets, V. A., Sizova, Z. M., Buslaev, S. I., \& Borodianskaia, E. A. (2020). Learning Styles and Development of Cognitive Skills in Mathematics Learning. Eurasia Journal of Mathematics, Science and Technology Education, 16(11). https://doi.org/10.29333/ejmste/8538

[19] Diehl, T. E., Hamman, K. J., \& Rivera, S. (2016). Group Study as a Form of Support for Developmental Mathematics Students. Learning Assistance Review, 25(1), 9-38.

[20] Sella, F., \& Cohen Kadosh, R. (2018). What Expertise Can Tell About Mathematical Learning and Cognition. Mind, Brain, and Education, 12(4), 186-192. https://doi.org/10.1111/ $\underline{\text { mbe. } 12179}$

[21] Mutlu, Y., \& Akgün, L. (2019). Using Computer for Developing Arithmetical Skills of Students With Mathematics Learning Difficulties. International Journal of Research in Education and Science, 5(1), 237-251.

[22] Alper Ardiç, M., \& İşleyen, T. (2017). High School Mathematics Teachers' Levels of Achieving Technology Integration and In-class Reflections: The Case of Mathematica. Universal Journal of Educational Research, 5(12B), 1-17. https://doi.org/10.13189/ ujer.2017.051401 
[23] Vidakis, N., Barianos, A. K., Trampas, A. M., Papadakis, S., Kalogiannakis, M., \& Vassilakis, K. (2019). In-Game Raw Data Collection and Visualization in the Context of the "ThimelEdu" Educational Game. In International Conference on Computer Supported Education (pp. 629-646). Springer, Cham. https://doi.org/10.1007/978-3-030-58459-7 30

[24] Qohar, A., Susiswo, S., Nasution, S. H., \& Wahyuningsih, S. (2021). Development of Android-Based Mathematics Learning Game on the Topic of Congruence and Similarity. International Journal of Interactive Mobile Technologies (IJIM), 15(9), 52. https://doi. org/10.3991/ijim.v15i09.20723

[25] Tatar, E., Akkaya, A., \& Kağizmanli, T. B. (2014). Using Dynamic Software in Mathematics: The Case of Reflection Symmetry. International Journal of Mathematical Education in Science and Technology, 45(7), 980-995. https://doi.org/10.1080/0020739X.2014.902129

[26] Ishtiaq, M. (2019). Book Review Creswell, J. W. (2014). Research Design: Qualitative, Quantitative and Mixed Methods Approaches (4th ed.). Thousand Oaks, CA: Sage. English Language Teaching, 12(5), 40. https://doi.org/10.5539/elt.v12n5p40

[27] Papadakis, S., \& Kalogiannakis, M. (2019). Evaluating the Effectiveness of a Game-based Learning Approach in Modifying Students' Behavioral Outcomes and Competence in an Introductory Programming Course. A Case Study in Greece. International Journal of Teaching and Case Studies, 10(3), 235-250. https://doi.org/10.1504/IJTCS.2019.10024369; https://doi.org/10.1504/IJTCS.2019.102760

[28] Ary, D., Lucy, J. C., Chris, S., \& Asghar, R. (2010). Introduction to Research in Education.

[29] Dingyloudi, F., \& Strijbos, J. W. (2020). Community Representations in Learning Communities. Scandinavian Journal of Educational Research, 64(7), 1052-1070. https://doi.org/10. $\underline{1080 / 00313831.2019 .1640788}$

[30] Virtue, E., Maddox, G., \& Pfaff, K. (2019). The Lasting Effects of Learning Communities. Learning Communities Research and Practice, 7(2), 6.

[31] David Gomillion, Aaron Becker, Jordana George, \& Michael Scialdone. (2020). Learning How to Teach: The Case for Faculty Learning Communities. Information Systems Education Journal, 18(4), 74-79

[32] Fisher, D., Frey, N., \& Almarode, J. (2020). Student Learning Communities as Builders of Collective Efficacy. Reading Psychology, 41(6), 559-582. https://doi.org/10.1080/0270271 1.2020 .1783139

[33] Wheeler, L., \& Tabbagh, D. (2020). Wyndham City: A Tale of Steady Progress Towards a Sustainable Learning Community. Australian Journal of Adult Learning, 60(3), 492-514.

[34] Gibson, H., Canfield, J., \& Beamish, A. (2020). Understanding Community Perceptions of Service- Learning. Journal of Service-Learning in Higher Education, 11(0), 5-20.

[35] Sætra, E. (2021). Discussing Controversial Issues in the Classroom: Elements of Good Practice. Scandinavian Journal of Educational Research, 65(2), 345-357. https://doi.org/10. $\underline{1080 / 00313831.2019 .1705897}$

[36] Mese, C., \& Ozgur, O. (2019). Effectiveness of Gamification Elements in Blended. Turkish Online Journal of Distance Education, 20(1302-6488), 119-142. https://doi.org/10.17718/ tojde. 601914

[37] Lai, C. H., Lin, H. W., Lin, R. M., \& Tho, P. D. (2019). Effect of Peer Interaction Among Online Learning Communities on Learning Engagement and Achievement. International Journal of Distance Education Technologies, 17(1), 66-77. https://doi.org/10.4018/ IJDET.2019010105

[38] Park, J. H., \& Byun, S. Yong. (2021). Principal Support, Professional Learning Community, and Group-level Teacher Expectations. School Effectiveness and School Improvement, 32(1), 1-23. https://doi.org/10.1080/09243453.2020.1764061 
[39] Dahl, L., Duran, A., Hooten, Z., Stipeck, C., \& Youngerman, E. (2020). Investigating the Influence of Residential Learning Communities on Student Experiences. Learning Communities Research and Practice, 8(1), 6.

[40] Thomas, M. L., Brown, G. G., Patt, V. M., \& Duffy, J. R. (2021). Latent Variable Modeling and Adaptive Testing for Experimental Cognitive Psychopathology Research. Educational and Psychological Measurement, 81(1), 155-181. https://doi.org/10.1177/0013164420919898

[41] Canals, L. (2017). Instruments for Gathering Data. Qualitative Approaches to Research on Plurilingual Education / Enfocaments Qualitatius per a La Recerca En Educació Plurilingüe / Enfoques Cualitativos Para La Investigación En Educación Plurilingüe, 390-401. https:// doi.org/10.14705/rpnet.2017.emmd2016.637

[42] Yayuk, E., Purwanto, As'Ari, A. R., \& Subanji. (2020). Primary School Students' Creative Thinking Skills in Mathematics Problem Solving. European Journal of Educational Research, 9(3), 1281-1295. https://doi.org/10.12973/eu-jer.9.3.1281

[43] Samura, A. O., Juandi, D., \& Darhim. (2020). Improving Mathematical Critical Thinking Skills Through Problem-based Learning. Journal of Physics: Conference Series, 1521(3). https://doi.org/10.1088/1742-6596/1521/3/032102

[44] Hake, R. R. (1998). Interactive-engagement Versus Traditional Methods: A Six-thousand-student Survey of Mechanics Test Data for Introductory Physics Courses. American Journal of Physics, 66(1), 64-74. https://doi.org/10.1119/1.18809

[45] Tamal, M. A., Akter, R., Hossain, S. A., \& Rezaul, K. M. (2021). A Weighted Scoring Based Rating Scale to Identify the Severity Level of Mathematics Anxiety in Students. International Journal of Interactive Mobile Technologies (IJIM), 15(8), 18. https://doi.org/10.3991/ ijim.v15i08.18627

[46] Orcan, F. (2020). Parametric or Non-parametric: Skewness to Test Normality for Mean Comparison. International Journal of Assessment Tools in Education, 7(2), 236-246. https:// doi.org/10.21449/ijate.656077

[47] Erps, R. C., \& Noguchi, K. (2020). A Robust Test for Checking the Homogeneity of Variability Measures and Its Application to the Analysis of Implicit Attitudes. Journal of Educational and Behavioral Statistics, 45(4), 403-425. https://doi.org/10.3102/1076998619883874

[48] Little, M. (2020). Collaboration and Connections among Middle School Teachers of Mathematics: Enhancing Efficacy through Professional Learning Communities. SRATE Journal, 29(1).

[49] Ludlow, A., Armstrong, R., \& Bartels, L. (2019). Learning Together: Localism, Collaboration and Reflexivity in the Development of Prison and University Learning Communities. Journal of Prison Education and Reentry, 6(1), 25-45.

[50] Zana H. Babakr, Pakstan Mohamedamin, \& Karwan Kakamad. (2019). Piaget's Cognitive Developmental Theory: Critical Review. Education Quarterly Reviews, 2(3), 517-524. https://doi.org/10.31014/aior.1993.02.03.84

[51] Cavanagh, M., \& McMaster, H. (2017). A Specialist Professional Experience Learning Community for Primary Pre-Service Teachers Focussed on Mathematical Problem Solving. Mathematics Teacher Education and Development, 19(1), 47-65.

[52] Skott, J. (2019). Understanding Mathematics Teaching and Learning "in Their Full Complexity." Journal of Mathematics Teacher Education, 22(5), 427-431. https://doi.org/10.1007/ $\underline{\text { s10857-019-09446-Z }}$

[53] Papadakis, S., Kalogiannakis, M., \& Zaranis, N. (2021). Teaching Mathematics With Mobile Devices and the Realistic Mathematical Education (RME) Approach in Kindergarten. Advances in Mobile Learning Educational Research, 1(1), 5-18. https://doi.org/10.25082/ AMLER.2021.01.002 
[54] Kurepa, A. (2019). The Design and Implementation of a Mathematics Learning Community. International Journal of Higher Education, 8(3), 77-82. https://doi.org/10.5430/ijhe. v8n3p77

\section{Authors}

Asri Ode Samura is a lecturer at Tadris Mathematics, Faculty of Tarbiyah and Teacher Training at the State Islamic Institute of Ternate Indonesia, and is now also a student of the Doctoral Program in Mathematics Education at the Indonesian Education University, Bandung. Active as a speaker in scientific forums at national or international conferences.

Darhim is a Professor at the Mathematics/S3 Education Study Program, Faculty of Mathematics and Natural Sciences, Universitas Pendidikan Indonesia Bandung. He is an active lecturer in research in mathematics education. He is a writer and reviewer in several national and international journals. He is also a speaker in scientific forums at national or international conferences.darhim@upi.edu

Dadang Juandi is a doctorate and senior lecturer at the Mathematics Education/S3 study program, Faculty of Mathematics and Natural Sciences, Universitas Pendidikan Indonesia Bandung. He is the head of the mathematics education/S3 study program and is active in Indonesian mathematics education organizations. He is a writer and reviewer in several national and international journals. He is also a speaker in scientific forums at national or international conferences. dadang.juandi@upi.edu

Arwan M. Said is a lecturer at Tadris Mathematics, Faculty of Tarbiyah, and Teacher Training at the State Islamic Institute of Ternate Indonesia. He is a writer in several national and international journals. arwanmhd@gmail.com

Muhlis Malaka is a lecturer at Tadris Mathematics, Faculty of Tarbiyah, and Teacher Training at the State Islamic Institute of Ternate Indonesia. He is a writer in several national and international journals.muhlis@iain-ternate.ac.id

Article submitted 2021-06-14. Resubmitted 2021-08-21. Final acceptance 2021-08-21. Final version published as submitted by the authors. 